Original Article

\title{
SUDDEN AND PREVALENT DEATHS OF FORAGING HONEY BEES IN EARLY SPRING DURING SOWING OF CLOTHIANIDIN COATED MAIZE SEEDS BETWEEN 2013 AND 2018 IN TURKEY
}

\author{
Hasan H. Oruç* \\ Meltem Çayci \\ Rashad Sariyev \\ Bursa Uludag University, Turkey \\ Corresponding author: oruc@uludag.edu.tr \\ Received: 17 April 2019; accepted: 21 January 2020
}

A bstract

Between 2013 and 2018, there was an outbreak of sudden foraging honey bee deaths in Turkey's Çukurova Region from the beginning of February to the middle of March, a period of time when the sowing of maize seeds occurs in the region. Upon returning, the affected bees were unable to enter the hive because of unbalanced flying and walking. Deaths were seen at apiaries located on plains or near plains where maize seeds were sowed. When winds blew from the direction of the plains towards the hives, honey bee deaths increased, but when the weather was rainy, honey bee deaths decreased or stopped. Honey bee losses were mainly between $30 \%$ and $80 \%$. Investigations related to the honey bee deaths were carried out in the affected apiaries using on-site inspection and laboratory tests. The main reason of deaths would be linked to the clothianidin coated maize seeds used in the plain during sowing period. No remarkable correlation with any bee pathogens was detected related to the sudden and prevalent honey bee deaths.

Keywords: clothianidin, honey bee deaths, maize seed, Turkey, weather conditions

\section{INTRODUCTION}

Honey bees are important for the balance of the ecosystem, contributing to the wider floral biodiversity and qualitative and quantitative characteristics of agricultural production. In addition, such honey bee products as honey, pollen, wax, propolis and royal jelly are appreciated for their importance in human consumption and the agricultural economy (Klein et al., 2007; Bacandritsos et al., 2010).

Honey bee deaths and population decline are a multifactorial issue involving such things as pesticide poisoning from agricultural activities, honey bee parasites ( Varroa destructor, Acarapis woodi), pathogens (Nosema spp. and bee viruses), contaminated water, nutritional stress and their interactions (Higes et al., 2008; Naug, 2009; vanEngelsdorp et al., 2009; Pistorius et al., 2009; Sharpe \& Heyden, 2009).

The use of pesticides in agricultural production is often discussed as a factor influencing bee health (Johnson et al., 2010). Honey bees can be exposed to pesticides through contaminated pollen and nectar collected and stored in the hive (Chauzat et al., 2006; Chauzat \& Faucon, 2007), through air contamination via the drifting of dust in coated seeds during sowing (Greatti et al., 2003; Тapparo et al., 2012), through the exudate excreted from the plants (Girolami et al., 2009), and through surface water (van Dijk, 2010). In addition to the reduction in the quality of hive products and the effects on bees' behavior, the accumulation of insecticides in honey bee tissue can also influence honey bee health and the colony population development, as they act as stressors for the entire colony. Compared to other insects, honey bees are extremely sensitive to pesticides due to a deficiency in the number of gene encoding detoxification enzymes (Claudianos et al., 2006). Intraspecific genetic differences also impact the susceptibility to pesticides, e.g., imidacloprid (Suchail, Guez, \& Belzunces, 2001).

Different classes of pesticides are used in agricultural activities, and the neonicotinoid class is 


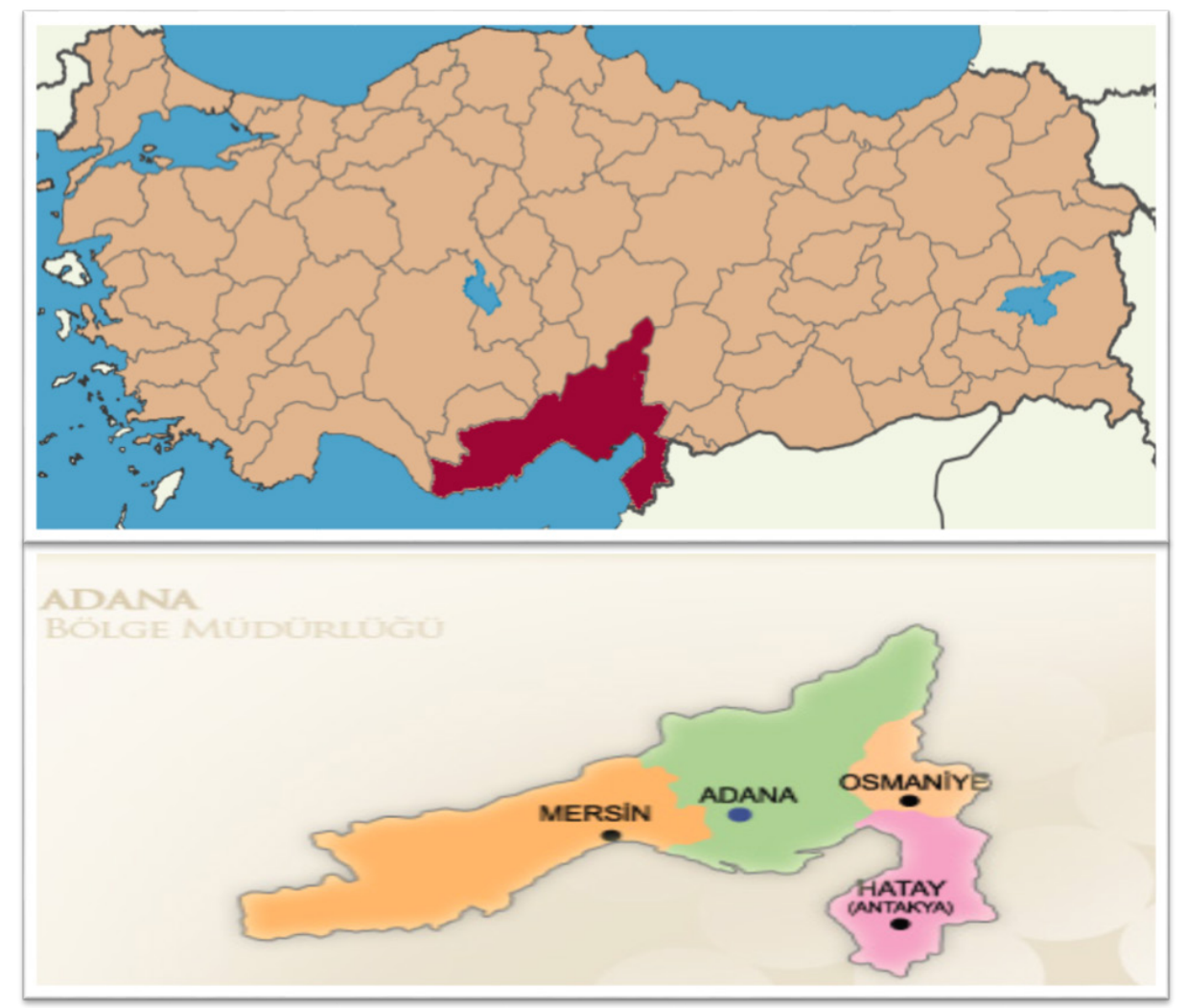

Fig.1. Location of the Çukurova Region in Turkey.

one of the types of the insecticides used. Neonicotinoid compounds are used in more than 120 countries, with at least 140 different crop uses (Jeschke et al., 2011; Lundin et al., 2015).

Nitro-substituted neonicotinoids, such as imidacloprid, clothianidin and thiamethoxam, are more toxic to bees (Kiljanek, Niewiadomska, \& Posyniak, 2016). The environmental releases of substances with recognized toxic and ecotoxic effects such as neonicotinoid insecticides have been associated with the worldwide crisis of honey bee colonies (Ratnieks \& Carreck, 2010; Tapparo et al., 2012). The European Commission voted to place a moratorium on the use of three neonicotinoid insecticides: imidacloprid, thiamethoxam and clothianidin, after the European Food Safety Authority (EFSA) determined that these products put bees at a high risk to through such exposure routes (EFSA, 2013) as direct dust exposure during seed planting operations (Greatti et al., 2003; Tapparo et al., 2012) and ingestion of residues in guttation droplets (Girolami et al., 2009), nectar and pollen from treated plants (Rortais et al., 2005). Taking into account these facts the European Commission (EC) proposed to restrict the use of three neonicotinoids: clothianidin, imidacloprid and thiamethoxam, for seed treatment, soil application (granules) and foliar treatment on bee attractive plants and cereals (EC, 2013; EFSA Technical Report, 2018), and toxicity risk of clothianidin when use as seed treatments was indicated by EFSA (EFSA, 2018). Similarly, neonicotinoids including acetamiprid, clothianidin, imidacloprid, thiacloprid and thiamethoxam were also restricted by the Ministry of Agriculture and Forestry in Republic of Turkey at the end of 2018 (Official Decision, 2018).

A high density of bee colonies is located in the Adana, Mersin, Osmaniye and Hatay provinces of southern Turkey's Çukurova Region (Fig. 1), due to the mild climate that promotes a rapid development of colonies in late winter (February) and early spring. This region is important for Turkey due to its having a fertile and large plain area for agricultural activities. For this reason, a high number of bee-attractive crops, such as fruit trees (plum, apricot, peach, nectarine and citrus fruits) and vegetables (cucumber, tomato, pepper and pumpkin), allow for the rapid development of colonies and good beekeeping conditions in early spring. Migratory beekeeping 
is also prevalent in this region.

Because bee death incidents have been observed on a large scale and are related temporally and spatially with the sowing of clothianidin-coated maize seeds, pesticides has been suspected of poisoning honey bees in the Cukurova Region. Maize seeds have recently been treated with clothianidin (Poncho ${ }^{\circ}$ FS 600) in this region for the eradication of the western corn rootworm (Diabrotica virgifera virgifera). Even though these sudden and prevalent deaths of honey bees with clinical symptoms were shown to be a poisoning case, bee pathogens had also been considered for differential diagnosis. Thus, the objective of this study was to investigate reasons for the sudden and prevalent honey bee deaths in early spring from 2013 to 2018 in the Çukurova Region.

\section{MATERIAL AND METHODS}

\section{Collection of samples, reporting and docu- mentation of bee deaths}

Dead honey bees and symptomatic adult honey bees were collected from affected apiaries from at the beginning of February until middle of March between 2013 and 2017 by Adana Directorate of Food, Agriculture and Livestock staff and experts of the Turkish and Adana Association of Beekeepers to be screened for chemical analysis and bee pathogen. For chemical analysis, fifty to one hundred dead honey bees were collected in small glass jars. Similiarly, the same numbers of symptomatic live bee samples were collected for bee pathogen screening and stored at $-20^{\circ} \mathrm{C}$ before being sent to laboratory to Adana, Pendik, Samsun and Etlik (Central) Institutes of Veterinary Control for chemical analysis and bee pathogen screening. The number of collected bee samples, years and results are shown in Tab. 1 according to the Adana Directorate of Food, Agriculture and Livestock (ADFAL) Report (ADFAL Report, 2017).

The highest number of bee deaths was recorded in 2017, a year when there was no rain during the period when maize was sowed in the region, and the highest number of samples $(n=129)$ was also collected in 2017 as shown in Tab. 1. The beekeepers were economically harmed between 2013 and 2018, especially in 2017. For this reason, expert researchers were tasked with assessing the bee deaths in the Cukurova Region, especially Adana and studied these sudden and extensive bee deaths in 2017 and 2018. Field investigations were carried out twice in Adana and Mersin during the period of honey bee deaths in 2017. AFDAL organized meetings in 2017 and prepared a report related to bee deaths from 2013 to 2017 (ADFAL Report, 2017). Neonicotinoids, including clothianidin, imidacloprid, acetamprid and thiamethoxam, were not analyzed due to a lack of laboratory conditions in Turkey for dead bees until 2018. However, five dead honey bee samples were analyzed for neonicotinoids from five different affected apiaries in the Seyhan, Yumurtalık, Yüreğir, Yeniyayla and Osmaniye districts collected in February 2018.

\section{Chemical analysis and bee pathogen screening of bee samples}

Chemical analysis of bees for pesticides was conducted at the Adana and Pendik Institutes of Veterinary Control and a private laboratory. The pesticides organochlorine, organophosphorus, carbamate, pyrethroids and others were screened and identified according to Albero, Sánchez-Brunete \& Tadeo (2004) by Gas chromatography-mass spectrometry (GC-MS) and according to Ferrer et al. (2005) by Liquid chromatography-tandem mass spectrometry (LC-MSIMS) instrumentation. Neonicotinoids clothianidin, acetamiprid, imidacloprid and thiamethoxam in bee samples were screened and identified by LC-MSIMS with triple quadrupole mass spectrometer QTRAP 4500 (Applied Biosystems MSD Sciex) coupled to a Perkin Elmer HPLC system. Extraction, purification, screening and identification were carried out according to Kasiotis et al. (2014). A single composite working standard solution of clothianidin, acetamiprid, imidacloprid and thiamethoxam (Sigma-Aldrich, St Louis, MO, USA) at $100 \mu \mathrm{gL}^{-1}$ was prepared in methanol and stored at $-20^{\circ} \mathrm{C}$. Working solutions at different concentrations were prepared by serial dilution in acetonitrile. 
Merck (Darmstadt, Germany) and LC-MS grade methanol and acetonitrile were used for the preparation of working solutions.

The limit of detection (LOD) and limit of quantification (LOQ) of the method have been determined 0.7 and $2.2 \mu \mathrm{g} / \mathrm{kg}$ for clothianidin, 0.5 and $1.6 \mu \mathrm{g} / \mathrm{kg}$ for imidacloprid, 0.3 and 1.0 $\mu \mathrm{g} / \mathrm{kg}$ for acetamiprid and 0.07 and $0.22 \mu \mathrm{g} / \mathrm{kg}$ for thiamethoxam. LOD was determined as the lowest concentration tested in which the peak signal was three times the background noise from the chromatogram in both transitions, and LOQ was determined as the lowest concentration tested in which the peak signal was ten times the background noise from the chromatogram regarding the quantitation transition and the ion ratio is consistent with the respective ratio of a standard. The mean recoveries were $75 \%, 79 \%, 89 \%$ and $78.33 \%$ with a relative standard deviations of $2 \%, 5.29 \%, 2 \%$ and $3.78 \%$ for clothianidin, imidacloprid, acetamiprid and thiamethoxam in bee matrices, respectively. Three samples of blank matrix were spiked at the fortification level of $50 \mu \mathrm{g} / \mathrm{kg}$ as for repeatability to determine recoveries.

Common bee pathogens Varroa destructor, Nosema ceranae, black queen cell virus (BQCV), deformed wing virus (DWV), Kashmir bee virus (KBV), chronic bee paralysis virus (CBPV) and American foulbrood (AFB) were screened for symptomatic adult honey bees at the Samsun and Etlik Central Institutes of Veterinary Control. Crushed adult bees were examined on a microscope slide for the detection of Nosema ceranae and Varroa destructor (OIE, 2008). The polymerase chain reaction (PCR) method using virus specific primers was applied for BQCV, DWV, KBV and CBPV detection (Martin et al., 2012). AFB detection was also performed with PCR technique by using a specific primer for the presence of Paenibacillus larvae subsp. larvae (Han et al., 2008).

\section{RESULTS}

The highest number of bee deaths was recorded in 2017 during the maize sowing period in the region, especially in Adana. Ten areas had sudden and extensive bee deaths in 530 apiaries in Adana, and 117556 colonies (83\%) out of 141606 colonies were damaged; 102669 (87\%) of the damaged colonies (117556) had honey bee losses over 30\%, and $14887(13 \%)$ of the damaged colonies had losses below 30\% (ADFAL Report, 2017). Sudden and extensive honey bee deaths with losses up to approximately $80 \%$ in some apiaries were observed from the beginning of February to the middle of March between 2013 and 2018. Clinical findings in dying bees were cramping, disoriented behavior, aggressiveness, abnormal wing movements and incapability to enter the hive, and there was sudden and high number of deaths of foraging bees in front of bee hives (Fig. 2).

Bee deaths have been observed on a large scale and are related temporally and spatially with the sowing of clothianidin-coated maize seeds in the Cukurova Region. When the wind blew from the plains to the hives during maize-seed sowing on the plains and when the apiary locations were as far as $15-25 \mathrm{~km}$ from the plains, honey bees

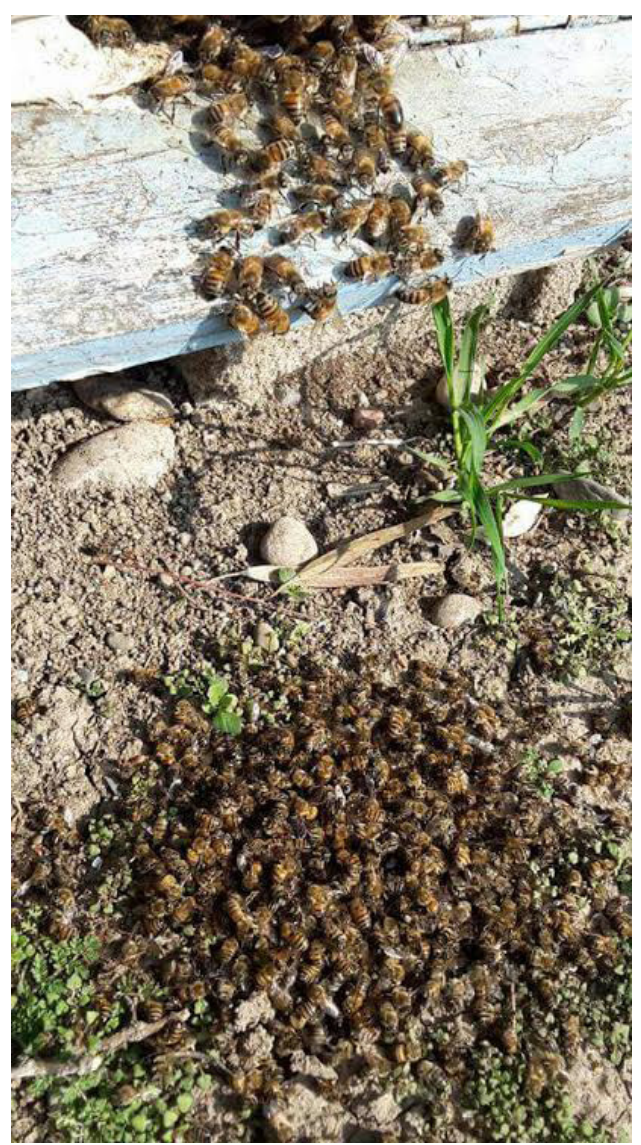

Fig. 2. High number of deaths of foraging bees in front of bee hives. 
Table 1.

The results of qualitative chemical analysis and bee pathogen screenings in bees in Adana

(ADFAL Report, 2017)

\begin{tabular}{|c|c|c|c|c|c|}
\hline Years & 2013 & 2014 & 2015 & 2016 & 2017 \\
\hline Number & 57 & 34 & 70 & 10 & 129 \\
\hline \multicolumn{6}{|c|}{ Pesticides } \\
\hline Amitraz & - & - & - & - & 1 \\
\hline Buprofezin & - & - & - & - & 1 \\
\hline Carbendazim & - & - & - & - & 14 \\
\hline Carbofuran & 7 & - & - & - & - \\
\hline Carbosulfan & 4 & - & - & - & - \\
\hline Chlorpyrifos & - & 2 & - & - & - \\
\hline Coumaphos & 17 & 9 & 12 & - & - \\
\hline Cyprodinil & - & - & - & - & 3 \\
\hline Dimethylacetamide & - & - & - & - & 4 \\
\hline Dimethylformamide & - & - & - & - & 6 \\
\hline Epoxiconazole & - & - & - & - & 8 \\
\hline Permethrin & 1 & - & - & - & - \\
\hline Pyridaben & - & - & - & - & 5 \\
\hline Tau-fluvalinate & 2 & 1 & 2 & - & - \\
\hline Tebuconazole & - & - & - & - & 5 \\
\hline Trifloxystrobin & - & - & - & - & 1 \\
\hline \multicolumn{6}{|l|}{ Bee pathogens } \\
\hline American foulbrood & - & - & - & 2 & 3 \\
\hline Nosema & 2 & - & 33 & 5 & 72 \\
\hline Varroa & - & - & - & - & 3 \\
\hline Black queen cell virus & - & 3 & 7 & 1 & 18 \\
\hline Chronic bee paralysis virus & - & - & - & - & 4 \\
\hline Deformed wing virus & - & - & - & - & 17 \\
\hline Kashmir bee virus & - & - & - & - & 9 \\
\hline
\end{tabular}

-: not determined

were affected and died. When the weather was rainy in the region, bee deaths decreased or stopped. The results of the analyzed pesticides except neonicotinoids and determined bee pathogens are shown in Tab. 1 (ADFAL Report, 2017). Clothianidin and acetamiprid residues were detected in five and two of five dead bee samples, respectively, and the results of clothianidin, imidacloprid, acetamprid and thiamethoxam analysis are presented in Tab. 2.

\section{DISCUSSION}

Researchers who searched bee deaths verified and claimed in clinical findings that there was a correlation between the acute pesticide poisoning and the sudden and high number of deaths of foraging bees in front of bee hives and that in dying bees there were cramping, disoriented behavior, aggressiveness, abnormal wing movements and incapability to enter the hive (Bortolotti et al., 2009; Pistorius et al., 
Table 2.

The results of chemical analysis for neonicotinoids in dead honey bees in this study (as $\mu \mathrm{g} / \mathrm{kg})$

\begin{tabular}{ccccc}
\hline Sample data & Clothianidin & Acetamprid & Imidacloprid & Thiamethoxam \\
\hline 1/Yumurtalık & 13 & 1 & - & - \\
2/Osmaniye & 10 & - & - & - \\
3/Yeniyayla & 9 & 2 & - & - \\
4/Seyhan & 7 & - & - & - \\
5/Yüreğir & 6 & - & - & - \\
Min-Max(n=5) & $6-13$ & $1-2$ & - & - \\
Positive rate & $(100 \%)$ & $(20 \%)$ & - & \\
\hline
\end{tabular}

Min-Max: Minimum-Maximum. - : Not detectable.

2015; Kiljanek, Niewiadomska, \& Posyniak, 2016; FAO, 2018). These were also harmonized with observed clinical findings in dying and death bees in this case related to acute pesticide poisoning (Fig. 2).

The results of the pesticides analysis (Tab. 1) did not support bee poisoning with the determined pesticides until 2018 because these pesticides were from different classes and were not harmonized from year to year between 2013 and 2017. In addition, such pesticides as carbendazim, epoxiconazole, tebuconazole, cyprodinil and coumaphos generally low or moderately toxic for honey bees. Although some pesticides, such as carbofuran and pyridaben, are highly toxic for honey bees, only one each was found in the dead bee samples in 2013 and 2017, respectively (Tab. 1). Therefore, a correlation was not observed between the determined pesticides and sudden and prevalent foraging bee deaths according to the Tab. 1 results.

Maize is cultivated in Turkey and in the Adana Province in the Cukurova Region varied from 89849.2 to 96737.0 hectares between 2013 and 2018. The sowing period of maize in the Cukurova Region lasts from the beginning of February to the middle of March, a period of time that coincides with the sudden and large number of bee deaths in the region. Sudden deaths in the Cukurova Region were also coincident when in Europe maize sowing from the middle of March to May was accompanied by a rapid disappearance and die-off of foraging bees in Germany (Pistorius et al., 2009), Italy
(Bortolotti et al., 2009), France (Chauzat et al., 2010) and in Slovenia (van der Geest, 2012) due to neonicotinoid pesticide poisonings from pesticides imidacloprid, thiamethoxam, and especially clothianidin.

The field research related to the sowing period of maize in spring and neonicotinoids, supported the hypothesis that solid particles emitted by drilling machines, which contained a high insecticide concentration, produced a direct powdering of foraging bees that were in free flight accidentally crossing the sowing fields (Marzaro et al., 2011; Girolami et al., 2012a; Girolami et al., 2012b; Tapparo et al., 2012). In the Cukurova Region, flying foraging bees may be acutely exposed to lethal doses $f$ in spring when maize is sown. Maize seeds have been recently treated with clothianidin (Poncho ${ }^{\circ}$ FS 600) in this region for eradication of the western corn rootworm. Neonicotinoids, including clothianidin, imidacloprid, acetamiprid and thiamethoxam, were not analyzed due to the lack of some laboratory conditions in Turkey for dead bees until 2018. However, clothianidin is an active substance from neonicotinoids and was detected in all five bee samples collected from the Cukurova Region in 2018 (Tab. 2). As compared in Tab. 2 and 3 , detected amounts of clothianidin were between 6 and $13 \mu \mathrm{g} / \mathrm{kg}$ in dead honey bees (Tab. 2) and was accordance with the results of previous studies (Tab. 3 ) in Germany (Pistorius et al., 2009), Slovenia (Public report, 2011; van der Geest, 2012), and Italy (Bortolotti et al., 2009). Although acetamprid was detected 
Table 3.

The results of chemical analysis for neonicotinoids in dead honey bees in previous studies (as $\mu \mathrm{g} / \mathrm{kg}$ and whole number)

\begin{tabular}{|c|c|c|c|c|c|}
\hline Sample data & $\begin{array}{l}\text { Clothianidin } \\
\text { positive rate }\end{array}$ & $\begin{array}{l}\text { Acetamprid } \\
\text { positive rate }\end{array}$ & $\begin{array}{l}\text { Imidacloprid } \\
\text { positive rate }\end{array}$ & $\begin{array}{l}\text { Thiamethoxam } \\
\text { positive rate }\end{array}$ & Reference \\
\hline $\begin{array}{l}\text { Min-Max (n=77) } \\
\text { Germany }\end{array}$ & 1-212 (92\%) & - & - & - & $\begin{array}{c}\text { Pistorius et al., } \\
2009\end{array}$ \\
\hline $\begin{array}{c}\text { Min-Max }(n=105) \\
\text { Italy }\end{array}$ & 3-39 (25\%) & - & $1-240(25 \%)$ & 24-138 (2\%) & $\begin{array}{c}\text { Bortolotti et al., } \\
2009\end{array}$ \\
\hline $\begin{array}{l}\text { Min-Max }(n=17) \\
\text { Slovenia }\end{array}$ & 5-18 (88\%) & - & $<5(12 \%)$ & $13-200$ (18\%) & $\begin{array}{c}\text { Public report, } \\
2011\end{array}$ \\
\hline
\end{tabular}

Min-Max: Minimum-Maximum. - : Not detectable.

in two samples, its quantities were very low (1 and $2 \mu \mathrm{g} / \mathrm{kg}$ ). On the other hand its toxicity is known not to be as high as clothianidin. In addition, maize seeds were coated with clothianidin (Poncho FS 600) in this region. Therefore, our results have shown that colony mortality was associated with the presence of clothianidin residues detected in honey bees, and the sudden and extensive deaths of foraging bees in the region coincided with the maize sowing period.

When the wind came from the direction of the plain to the hives during the sowing of maize seeds on the plains and when the apiary locations were as far as $15-25 \mathrm{~km}$ from the plain, some honey bees were affected and died. The air contained high levels the dust of such insecticides as neonicotinoids from the sowed maize fields (Marzaro et al., 2011; Girolami et al., 2012a; Girolami et al., 2012b; Tapparo et al., 2012). Thus, high concentration of insecticides could reach distant hives by wind. When the region experienced rainy weather in bee deaths decreased or stopped because neonicotinoids are watersoluble (Wood \& Goulson, 2017) and neonicotinoid dust in the air can easily be washed off by rain. The main reason for the highest numbers of bee deaths in 2017 was a lack of rain during the maize sowing period.

Sudden and prevalent bee deaths between 2013 and 2018, especially in 2017, caused high economical, moral and motivational damage for beekeepers located in this region. The honey bee deaths in 2018 were much fewer than those in 2017 because beekeepers located in the region had been warned of sudden honey bee deaths before the maize sowing period and accordingly did not generally localize to the region during the 2018 maize sowing period. In addition, there was regular rainfall in the region during this period.

Symptomatic adult honey bees tested positive for Varroa destructor, Nosema spp., BQCV, DWV, KBV, CBPV and AFB. The sudden and prevalent bee deaths in the springtime occurring from the beginning of February to the middle of March are chronologically distinguishable from bee deaths caused by Varroa destructor and other bee pathogens. However, a close relationship was observed between the bee deaths and the use of pneumatic drilling machines for the sowing of corn seeds coated with clothianidin in the Çukurova Region. In conclusion, the field studies in affected apiaries, on-site inspection and chemical analyses confirmed that clothianidin poisoning during the maize sowing period was related to the sudden and prevalent bee deaths in the Çukurova Region between 2013 and 2018.

\section{ACKNOWLEDGMENTS}

The authors would like to thank the Turkish and Adana Association of Beekeepers and the Adana Directorate of Agriculture and Forestry for supporting of this research.

\section{REFERENCES}

ADFAL (Adana Directorate of Food, Agriculture and 
Livestock) Report, (2017). Adana ilinde yaşanan arı ölümlerinin nedenleri, yapilan çalışmalar ve çözüm önerileri raporu (English: Report of bee losses reasons, background studies and suggested solutions in Adana city). Ministry of Agriculture and Forestry in Republic of Turkey (pp:1-10).

Albero, B., Sánchez-Brunete, C., \& Tadeo, J.L. (2004). Analysis of Pesticides in Honey by Solid-Phase Extraction and Gas Chromatography-Mass Spectrometry. The Journal of Agricultural and Food Chemistry,52(19), 5828-5835. DOl: 10.1021/jf049470t

Bacandritsos, N., Granato, A., Budge, G., Papanastasiou, l., Roinioti, E., Caldon, M., ... Mutinelli, F. (2010). Sudden deaths and colony population decline in Greek honey bee colonies. Journal of Invertebrate Pathology, 105(3), 335-340. D0l: 10.1016/j. jip.2010.08.004

Bortolotti, L., Sabatini, A. G., Mutinelli, F., Astuti, M., Lavazza, A., Piro, R.,... Porrini, C. (2009). Spring honey bee losses in Italy. Julius-Kühn Archiv, 423, 148-152.

Chauzat, M. P., \& Faucon, J. P. (2007). Pesticide residues in beeswax samples collected from honey bee colonies (Apis mellifera L.) in France. Pest Management Science, 63(11), 1100-1106. DOl: 10.1002/ ps.1451

Chauzat, M. P., Faucon, J. P., Martel, A. C., Lachaize, J., Cougoule, N., Aubert, M. (2006). A survey of pesticide residues in pollen loads collected by honey bees in France. Journal of Economic Entomology, 99(2), 253-262. DOl: 10.1603/0022-0493-99.2.253

Chauzat, M. P., Martel, A. C., Blanchard, P., Clément, M. C., Schurr, F., Lair, C., ... Faucon, J. P. (2010). A case report of a honey bee colony poisoning incident in France. Journal of Apicultural Research, 49(1), 113115. DOI: 10.3896/IBRA.1.49.1.22

Claudianos, C., Ranson, H., Johnson, R. M., Biswas, S., Schuler, M. A., Barenbaum, M. R.,... Oakeshott, J. G. (2006). A deficit of detoxification enzymes: pesticide sensitivity and environmental response in the honeybee. Insect Molecular Biology, 15(5), 615- 636. DOl: 10.1111/j.1365-2583.2006.00672.x
EC (European Commission), (2013). Commission Implementing Regulation (EU) No 485/2013. Amending Implementing Regulation (EU) No 540/2011, as regards the conditions of approval of the active substances clothianidin, thiamethoxam and imidacloprid, and prohibiting the use and sale of seeds treated with plant protection products containing those active substances. Official Journal of the European Union, L 139/12-26.

EFSA (European Food Safety Authority), (2013). Conclusion on the peer review of the pesticide risk assessment for bees for the active substance imidacloprid. European Food Safety Authority Journal, 77(1), 3068. DOl: 10.2903/j.efsa.2013.3068

EFSA (European Food Safety Authority), (2018). Conclusion on the peer review of the pesticide risk assessment for bees for the active substance clothianidin considering the uses as seed treatments and granules. EFSA Journal, 16(2), 5177, 86 pp. DOl: 10.2903/j.efsa. 2018.5177

EFSA (European Food Safety Authority), Technical Report, (2018). Evaluation of the data on clothianidin, imidacloprid and thiamethoxam for the updated risk assessment to bees for seed treatments and granules in the EU. EFSA Supporting publication. DOl:10.2903/sp.efsa.2018.EN-1378

FAO (2018). A. Bee-poisoning symptoms, Chapter 7, pesticides and beekeeping. Retrieved March 26, 2018, from http://www.fao.org/docrep/x0083e/ X0083E09.htm

Ferrer, l., García-Reyes, J.F., Mezcua, M., Thurman, E.M., Fernánndez-Alba, A.R. (2005). Multi-residue pesticide analysis in fruits and vegetables by liquid chromatography-time-of-flight mass spectrometry. Journal of Chromatography A, 1082(1), 81-90. DOl: 10.1016/j.chroma.2005.03.040

Girolami, V., Marzaro, M., Vivan, L., Giorio, C., Marton, D., Tapparo, A. (2012a). Aerial powdering of bees inside mobile cages and the extent of the toxic neonicotinoid cloud surrounding corn drillers. Journal of Applied Entomology, 137, 35-44. DOl: 10.1111/j.1439- 


\section{J. APIC. SCLI. VOL. 64 NO. 12020}

0418.2012.01718.x

Girolami, V., Marzaro, M., Vivan, L., Mazzon, L., Greatti, M., Giorio, C., ... Tapparo, A. (2012b). Fatal powdering of bees in flight with particulates of neonicotinoids seed coating and humidity implication. Journal of Applied Entomology, 136(1-2), 17-26. DOl: 10.1111/j.1439-0418.2011.01648.x

Girolami, V., Mazzon, L., Squartini, A., Mori, N., Marzaro, M., Di Bernardo, A., ... Tapparo, A. (2009). Translocation of neonicotinoid insecticides from coated seeds to seedling guttation drops: A novel way of intoxication for bees. Journal of Economic Entomology, 102(5), 1808-1815. DOl: 10.1603/029.102.0511

Greatti, M., Sabatini, A. G., Barbattini, R., Rossi, S., Stravisi, A. (2003). Risk of environmental contamination by the active ingredient imidacloprid used for corn seed dressing. Preliminary results. Bulletin of Insectology, 56(1), 69-72.

Han, S.H., Lee, D.B., Lee, D.W., Kim, E.H., Yoon, B.S. (2008). Ultra-rapid real-time PCR for the detection of Paenibacillus larvae, the causative agent of American Foulbrood (AFB). Journal of Invertebrate Pathology, 99(1), 8-13. DOl:org/10.1016/j. jip.2008.04.010

Higes, M., Martín-Hernández, R., Botías, C., Bailón, E., González-Porto, A., Barrios, L., ... Meana, A. (2008). How natural infection by Nosema ceranae causes honey bee colony collapse. Environmental Microbiology, 1010), 2659-2669. DOl: 10.1111/j.14622920.2008.01687.x

Jeschke, P., Nauen, R., Schindler, M., Elbert, A. (2011). Overview of the status and global strategy for neonicotinoids. Journal of Agricultural and Food Chemistry, 59(7), 2897-2908. DOl: 10.1021/jf101303g

Johnson, R. M., Ellis, M. D., Mullin, C. A., Frazier, M. (2010). Pesticides and honey bee toxicity-USA. Apidologie, 47(3), 312-31. DOl: 10.1051/apido/2010018

Kasiotis, K.M., Anagnostopoulos, C., Anastasiadou, P. Machera, K. (2014). Pesticide residues in honeybees, honey and bee pollen by LC-MS/MS screening: reported death incidents in honeybees. Scince of the Total Environment, 7(485-486), 633-642. DOl: 10.1016/j.scitotenv.2014.03.042

Kiljanek, T., Niewiadowska, A. \& Posyniak, A. (2016). Pesticide Poisoning of Honeybees: A Review of Symptoms, Incident Classification, and Causes of Poisoning. Journal of Apicultural Science, 602), 5-24. DOI: 10.1515//AS-2016-0024

Klein, A. M., Vaissile, B. E., Cane, J. H., Steffan-Dewenter, I., Cunningham, S. A., Kremen, C., Tscharntke, T. (2007). Importance of pollinators in changing landscapes for world crops. Proceedings of the Royal Society B: Biological Sciences, 274, 303-313. DOl: 10.1098/rspb.2006.3721

Lundin, O., Rundlöf, M., Smith, H. G., Fries, I., Bommarco, R. (2015). Neonicotinoid Insecticides and Their Impacts on Bees: A Systematic Review of Research Approaches and Identification of Knowledge Gaps. PloS ONE, 108): e0136928. DOl: 10.1371/journal.pone.0136928

Martin, S.ı., Highfield, A.C., Brettel, L., Villalobos, E.M., Budge, G.E., Powell, M.,... Schroeder, D.C. (2012). Global honey bee viral landscape altered by a parasitic mite. Science,(336), 1034-1036. DOl: 10.1126/science.1220941

Marzaro, M., Vivan, L., Targa, A., Mazzon, L., Mori, N., Greatti, M., ... Girolami, V. (2011). Lethal aerial powdering of honey bees with neonicotinoids from fragments of maize seed coat. Bulletin of Insectology, 64(1), 119-126.

Naug, D. (2009). Nutritional stress due to habitat loss may explain recent honey colony collapses. Biological Conservation, 142(10), 2369-2372. DOl: 10.1016/j.biocon.2009.04.007

Official Decision (2018). Neonicotinoid Grubu Aktif Maddelerin Yasaklanması ve Kisıtlanması Hk. (English: As regards the conditions of prohibition and restrict of the active substances of neonicotinoid group). General Directorate of Food and Control, Ministry of Agriculture and Forestry in Republic of Turkey. Retrieved April 17, 2019, from https://bku.tarim.gov.tr/ 
Duyuru/DuyuruDetay/32

OIE (All World Organisation for Animal Health) (2008). Nosemosis of honey bees. Chapter 2.2.4. In Manual of Diagnostic Tests and Vaccines for Terrestrial Animals. (pp. 410-414). Paris: OIE Terrestrial Manual.

Pistorius, J., Bischoff, G., Heimbach, U., Stähler, M. (2009). Bee poisoning incidents in Germany in spring 2008 caused by abrasion of active substance from treated seeds during sowing of maize. Julius Kühn Archiv, 423, 118-126.

Pistorius, J., Wehner, A., Kriszan, M., Bargen, H., Knäbe, S., Klein, O.,... Heimbach, U. (2015). Application of predefined doses of neonicotinoid containing dusts in field trials and acute effects on honey bees. Bulletin of Insectology, 68(2), 161-172.

Public report (2011). Bee poisoning incidents in the Pomurje region of Eastern Slovenia in 2011. Based on the public report by the Inspectorate of the Republic Slovenia for Agriculture Forestry and Food. Retrieved April 16, 2019, from www.nationalbeeunit.com/downloadDocument.cfm?id=639

Ratnieks, F. L. W., \& Carreck, N. L. (2010). Clarity on honey bee collapse? Science, 3275962), 152-153. DOl: 10.1126/science.1185563

Rortais, A., Arnold, G., Halm, M. P., Touffet-Briens, F. (2005). Modes of honeybees exposure to systemic insecticides: estimated amounts of contaminated pollen and nectar consumed by different categories of bees. Apidologie, 36(1), 71-83. DOI: 10.1051/ apido:2004071

Sharpe, J. R., \& Heyden, L. C. (2009). Honey bee colony collapse disorder is possibly caused by a dietary pyrethrum deficiency. Bioscience Hypotheses, 2(6), 439-440. DOl: 10.1016/j.bihy.2009.01.004

Suchail, S., Guez, D., \& Belzunces, L. P. (2001). Discrepancy between acute and chronic toxicity induced by imidacloprid and its metabolites in Apis mellifera. Environmental Toxicology and Chemistry, 2011), 2482- 2486. DOl: 10.1002/etc.5620201113
Tapparo, A., Marton, D., Giorio, C., Zanella, A., Soldà, L., Marzaro, M., ... Girolami, V. (2012). Assessment of the environmental exposure of honeybees to particulate matter containing neonicotinoid insecticides coming from corn coated seeds. Environmental Science Technology, 46(5), 2592-9. DOl: 10.1021/ es2035152

van der Geest, B. (2012). Bee poisoning incidents in the Pomurje region of Eastern Slovenia in 2011. Hazards of pesticides to bees. Julius-Kühn-Archiv, 437, 124. DOl: 10.5073/jka.2012.437.036

van Dijk, T. (2010). Effects of neonicotinoid pesticide pollution of Dutch surface water on nontarget species abundance [MSc Thesis] Utrecht University.

van Engelsdorp, D., Evans, J. D., Saegerman, C., Mullin, C., Haubruge, E., Nguyen, B. K., ... Pettis, J. S. (2009). Colony collapse disorder: a descriptive study. PLoS ONE, 4(8), e6481. DOl: 10.1371/journal. pone.0006481

Wood, T. J., \& Goulson, D. (2017). The environmental risks of neonicotinoid pesticides: a review of the evidence post 2013. Environmental Science and Pollution Research, 24(21), 17285-17325. DOl: 10.1007/ s11356-017-9240-x 